\title{
CHARITY LAW AS A POLITICAL OPTION FOR THE POOR
}

\author{
Alison Dunn, Lecturer in Law, Newcastle Law School, University of \\ Newcastle-upon-Tyne \\ INTRODUCTION*
}

In current charity law, and in the wider voluntary sector, there has been much debate over the extent to which charities may undertake political acts or become involved, generally or specifically, in the political process. The question concerning the involvement of charity in the political arena is one that has had a relatively short but involved history, with particular controversy spanning from the Charity Commission's inquiry into Oxfam's activities, ${ }^{1}$ the increasing scrutiny of the nature and content of charity advertising, ${ }^{2}$ to the debates over protection of donors and taxpayers, and claims for freedom of expression, freedom of association and basic human rights. ${ }^{3}$ The arguments which have been advanced for the restriction on political activities by charities include the need for the judiciary to remain politically neutral; the inability of the Charity Commission or the judiciary to assess whether political conduct will be for the public benefit, an essential requirement within charity law for an act to be charitable; the view that the functions of the legislature should not be

\footnotetext{
* This paper was delivered at an International Colloquium on the Foundations of Charity at King's College in September 1998. The author is particularly grateful to the Colloquium organiser, John Gardner, for his assistance and for his comments on an earlier draft; to the Colloquium participants for their discussion of the issues raised by this research; to Roger Brownsword, Ilona Cheyne, Ian Dawson, Peter Luxton and Mia Murillo for their comments on an earlier draft; Dylan Griffiths, Chris Hughes, Clare McGlynn, Richard Mullender and Peter Oliver for their suggestions of helpful material; and Jonathan Garton and James Watson for their research assistance.

1 S M St Clare Smith \& Charity Commission, OXFAM: Report of an inquiry submitted to the Charity Commissioners 8 April 1991, including the response of the Charity Commissioners (1991).

2 For example, Christian Aid's advertising campaign to highlight suffering caused by Third World debt was held to breach Art 10 of the ITC Code as used to achieve political ends, see The Times, 16 December 1997. Earlier, in 1995, the Advertising Standards Authority upheld complaints against various charities concerning similar political and emotive advertisements: ASA, Report No. 53 (London: ASA, 1995).

3 See, inter alia, Burt, "Charities and Political Activity: Time to Rethink the Rules" (1998) Political Quarterly 23; Chesterman, Charities, Trusts and Social Welfare (1979); Chisholm, "Politics and Charity: A Proposal for Peaceful Coexistence" (1990) 58 George Washington Law Review 308; Clark, "The Limitation on Political Purposes: A Discordant Note in the Law of Charities" (1960) 46 Virginia Law Review 439; Rickett, "Charity and Politics" (1982) 10 NZULR 169; Sheridan, "Charity Versus Politics" (1973) 2 Anglo-American Law Review 47; 6 \& Randon, Liberty, Charity \& Politics: Non-Profit Law and Freedom of Speech (1996).
} 
usurped; and, more generally, the protection of donors to charities who may not wish their donations to be used for political purposes. ${ }^{4}$

It may be argued that the position has clarified: that the guidance given by the Charity Commission ${ }^{5}$ plus interpretative case law provides a reasonably comprehensive picture of the permissive political activities that charities may undertake. It is certainly true that charities are permitted to employ a range of political activities, providing they remain ancillary to and in furtherance of the charity's main purpose. ${ }^{6}$ But it is equally true that despite the guidelines and their effect of fostering a healthy debate on charitable political activities, the legal and practical position is neither clear nor settled. ${ }^{7}$ The extent to which charities are permitted to be political remains constrained. Boundaries per se may not be problematic where they are grounded on rational criteria, but in this context some of the limits upon charities are arbitrary, and quite often it proves to be not a charity's actual message which infringes the rules, but rather how it decides to convey it. More seriously, the restrictions are arguably based upon unreasoned and misconstrued case law which may owe much to public policy, but little to rigorous jurisprudential analysis.

Beyond the policy of the law there remain serious practical issues which impress upon charities the (predominantly financial) problems inherent in their undertaking the political acts open to them under the law. Some charities, for example, are restrained by their umbrella bodies, and there is evidence to suggest that corporate sponsors may have a role in limiting

${ }^{4}$ Charities: A Framework for the Future Cm 694 (1989), chapter 2; and see inter alia, the cases in $\mathrm{n} 9$ below.

5 Charity Commission Leaflet CC9 Political Activities and Campaigning by Charities (1995, reissued 1997); Charity Commission Leaflet CC9a Political Activities and Campaigning by Local Community Charities (1997). For comment see A. Dunn, "Charity Law - A Political Scandal?" [1996] 2 Web JCLI.

6 Accordingly, charities may undertake a political activity, such as influencing government or public opinion, organising and presenting petitions, responding to proposed legislation or providing members with information to send to their Members of Parliament, where such activity furthers or is reasonably expected to further the charitable purposes of the charity, is within the powers of the charity trustees, is consistent with all the provisions of the Charity Commission's guidelines and the case put forward by the charity and its views are well-founded, reasoned and responsibly expressed (Charity Commission leaflet CC9 n 6 above, para 14, and Charity Commission leaflet CC9a n 6 above, para 5).

7 The paucity of cases has meant that few issues are clarified at judicial level. As testament to the uncertainty in and understanding of the law, the Deakin Commission revealed that the question of the political activities of charities was an issue in frequent evidence before them years after the guidance by the Charity Commission was first produced: Report of the Commission on the Future of the Voluntary Sector (1996), Vol. 1, para 3.5.12.

8 The case law developed in the early part of this century from a statement made by Lord Parker in Bowman v Secular Society Ltd [1917] AC 406. Although strictly obiter, his view was endorsed in subsequent cases, and a general rule laid down in National Anti-Vivisection Society v IRC [1948] AC 31. A more comprehensive prohibition was set out by Slade J in McGovern v Att Gen [1982] Ch 321 and has been endorsed ever since (though cf Public Trustee v Attorney General of New South Wales (1997) 42 NSWLR 600). 
legitimate political activity. ${ }^{9}$ Corporate donors often choose charities which give them a particular profile, for example, a caring or ecological face, and will not wish to be associated with a charity which undertakes overt political acts. Further, contracts to provide services often have the effect of preventing the charity speaking out. As Lord Astor of Hever recently commented in a House of Lords' debate on the future of charities: "With so much of the charities' money coming from government sources, many charities lack genuine freedom of action." 10

Moreover, the (largely twentieth century ${ }^{11}$ ) preoccupation of the law with charitable neutrality is misplaced given that charity works and exists on the periphery, dealing with partial circumstances. The modern law's concern with the extent to which charities may be political will always create tension where it fails to take into account an understanding of the nature of charity itself and an understanding of the basis of politics. This article undertakes such an examination and argues that there is much common ground between the political and charitable spheres, most particularly in that they are unified by their concern with public benefit, or the common good. The tensions in law between charity and politics are mirrored in the theology arena, and this article goes on to draw a comparison with the area of liberation theology which teaches that at its inception charity leads to a political option for the poor. Although criticised for being distortionary, exclusionary and for having false legitimacy, liberation theology has forced an institutional reconsideration of fundamental principles. A similar reconsideration needs to take place in law and this article concludes with some options for reform which may enable charity law to more fully reflect the nature of the arena it regulates.

\section{CONSTRUING 'POLITICS'}

The consistent occurrence of political scandals has done much to encourage a conception of politics as self-serving and narcissistic, and this often accounts for the general uneasiness which surrounds the involvement of charity in the political sphere. Although regrettable, such instances make up no more than the outer layer of a much more complex notion.

'Politics' and 'political activity' have both been variously defined, though unity can be found in an analysis of the different meanings. Modern definitions posit 'political' as any act which is 'of the state' and which relates to 'the art and science of government'. ${ }^{12}$ In law too, definitions similar to the above abound, albeit that these definitions are not necessarily consistent, since interpretation has to be placed within the context and purpose of each particular jurisdiction. ${ }^{13}$ Lord Diplock, for

Beishon, "Homelessness and Company Giving" (1995) 16 Policy Studies 49.

${ }_{10}$ HL Deb vol 586, col 1213-1214, 4 March 1998.

11 As Francis Gladstone rightly pointed out, many of the great nineteenth century reforming charities would clearly have infringed the present rules: Charity, Law and Social Justice (1982). See also Lord Porter's dissenting judgment in National Anti-Vivisection Society v IRC, $\mathrm{n} 9$ above.

12 Typical of which is that to be found in the Oxford Politics Dictionary.

13 The context in which an act occurs can be very important to an analysis of its political nature. This is particularly so in current charity law where an ordinarily political act will not be considered political where it is ancillary to a charitable purpose, and vice versa. This point, emphasised in McGovern v Att Gen $\mathrm{n} 9$ above, was reiterated most recently in $R \mathrm{v}$ Radio Authority, ex $p$ Bull 
example, stated in Tzu-Tsai Cheng v Governor of Pentonville Prison ${ }^{14}$ in the context of the law of extradition, that "... politics are about government. 'Political' as descriptive of an object to be achieved must, in my view, be confined to the object of overthrowing or changing the government of a state or inducing it to change its policy." Similarly, in the context of charity law, Slade J's view in McGovern v Attorney General ${ }^{15}$ was that 'political' pertained to furthering the interests of a particular political party, procuring changes in the laws of this or of a foreign country, or procuring a reversal of government policy or decisions of governmental authorities in this or in a foreign country. More broadly, $R$ $\mathrm{v}$ Radio Authority, ex $p$ Bull, ${ }^{16}$ a case concerning construction of the term 'political' in the context of the Broadcasting Act 1980, endorsed the approach in Tzu-Tsai Cheng and McGovern and defined 'political' as including an act which pertained to government policy, McCullough $\mathbf{J}$ stating at first instance that: "Once the matter has become the subject of government policy, or once the need for legislation about it is advocated, particularly if the matter has become contentious, then, as it seems to me, it is open ... to treat it as 'political'."17

Accordingly, 'politics' may be allied with the actions of government, and concerns a process where the differing, often conflicting needs and interests of individuals, communities, or nations, are reconciled, accommodated or furthered. This may be achieved directly through legislation, or indirectly through the adoption of a range of policies or the pursuit of a fundamental ideology. Here politics has many layers of activity and complexity. On the one hand, as a connotation of government it is concerned with hard choices with regard to the distribution of scarce or limited resources, the extent and nature of protective action and the accommodation of one set of interests or needs with another. But supporting that level of activity is another which leads to it, commonly perceived as the process of consultation and deliberation which provides the foundation to reasoned governmental decision-making.

These notions and the prevalent political debate thus directly associate politics with government and actions which are indeed 'of the state'. However, it would be a misconception to polarise the political to this institutional arena. Whilst taking care not to debase the notion entirely, it is clear that by delving within and beyond the art and science of government one finds that politics and its associated notions exhibit more fundamental qualities concerning the interrelationship between members of any given community and between communities. Thus, 'politics' as a process of policy formulation and decision-making to reconcile the interests of the community does not simply exist on the macro - or

[1998] QB 294 - see particularly M.R Woolf and L.J. Aldous See further text to n $42-43$ below.

14 [1973] AC 931, 945

15 n 9 above, 340 .

16 [1995] 4 All ER 481,[1998] QB 294 (Court of Appeal). In some circumstances a political activity can also be described as a business activity; see the decision of the Court of Appeal in Commissioners of Customs \& Excise v British Field Sports Society, The Times, 4 February 1998, in which the political campaigning, lobbying and related public relations activities of the British Field Sports Society were deemed to be business activities within the meaning of section 47(2)(a) of the Value Added Tax Act 1983.

17 ibid, 500 . 


\section{Northern Ireland Legal Quarterly [Vol. 50, No. 3]}

governmental - scale. Politics equally forms part of the relations between individuals within the community, thus operating on a micro-level. ${ }^{18}$ This can be seen in a quasi-institutional sense, such as within the world of commerce or business, the church or the family, but it similarly exists where any unit of persons become bound up as a social group.

Current trends in society and in social organisation indicate that political activity has become more vibrant and effective on this micro, or as Beck has termed it, 'sub-political' level. ${ }^{19} \mathrm{He}$ argues not only that "the individual is returning to society", but that in fact "the political constellation of industrial society is becoming unpolitical, while what was unpolitical in industrialism is becoming political": that is, that the emphasis upon political activity as falling within the exclusive remit of government no longer holds true. The bolstering of micro-level politics has both vertical and horizontal causes. The process of consultation from the government downwards demands discussion with interested individuals and groups within society. ${ }^{20}$ The promulgation of a healthy civil society ${ }^{21}$ which this necessitates likewise has an effect upon the prevalence of groups who can capitalise upon explicit or implicit notions of citizenship. ${ }^{22}$ In this horizontal context it can indeed be seen that "man moves man". ${ }^{23}$

Politics can then be defined as the act of reconciling and furthering the interests within communities on both a micro or macro-level. Though it may appear that the meaning of politics differs across these two levels, in a pure sense they are unified by the purpose for which conciliation or advancement is sought. Whether one is concerned with the state or a nuclear unit, the aim of accommodating or promoting diverse interests is the achievement of a status quo which is of preponderant value to the unit,

18 Beck, The Reinvention of Politics: Rethinking Modernity in the Global Social Order (1997), 99.

19 Ibid, 98, 99 (original italics). See also Sachs, The Politics of Hope (1997), 137138, 237.

20 Crick, In Defence of Politics (4th ed, 1993), 33. The role of the voluntary sector within the political arena has long been lauded as an essential prerequisite for a healthy civil and political society: see further text to $\mathrm{n} 88-90$ below.

21 Civil society takes as its root the positive contribution that can be made by citizens as conscientious actors in the political process: see, for example, Ndegwa, The Two Faces of Civil Society: NGOs and Politics in Africa (1996); and the comments made by Baroness Pitkeathley in a recent House of Lords' debate: HL Deb vol 586, col 12564 March 1998, and see also Lord Astor, col 1214; Baroness Young, col 1216; Baroness Linklater of Butterstone, col 1225.

22 On an explicit level, citizenship is one of the key concepts within the European Union, though the EU notion of citizenship may be more exclusionary than the term would indicate, see Ward, "(Pre)conceptions in European Law" (1996) 23 Journal of Law and Society 198

23 de Jouvenal, The Pure Theory of Politics (1963), x, and see generally $77 \mathrm{ff}$. For an early examination of the concept of citizenship see Ferguson, An Essay on the History of Civil Society 1767 (1966). A study into citizenship and civil society has more recently been launched by the Commonwealth Foundation. The project aims to identify ways in which citizenship and civil society can be strengthened and promoted. Consultation across the Commonwealth is currently in process. 
the community or to society as a whole. ${ }^{24}$ At a more fundamental level, therefore, politics and political activity may be said to pertain to promoting a common good, or commonly held values, acting for the public benefit and transforming the parts of society which fall short of a shared social standard. ${ }^{25}$

\section{CONSTRUING 'CHARITY'}

Much of what has been noted above about the realm and ambit of politics transcends into the charitable sphere, from difficulty over definition to its fundamental philosophy.

The very word 'charity' is chameleonic, having the tendency to take on different meanings according to both the circumstances in which it is used, and the person using it. 'Charity' stems from the Latin term 'caritas' connoting regard, esteem, affection or love. ${ }^{26}$ According to Story: "Whatever is given for the love of God or the love of your neighbour, in the catholic and universal sense - given from these motives and to these ends - free from the stain or taint of every consideration that is personal, private or selfish, is a charity." 27

But it is clear that in this non-legal sense, the term charity has a number of varied connotations. The definition provided by the Oxford English Dictionary, for example, concentrates upon charity's both Christian and non-specifically Christian aspects. With regard to the former, Biblical connotations of charity relate to its intrinsic relationship with love. ${ }^{28}$ Alternatively, "without any specially Christian connotations [charity is] love, kindness, affection, natural affection... especially with some notion of generous or spontaneous goodness", and more precisely it is "benevolence to one's neighbours, especially to the poor; [and] the practical benefices of which this manifests itself".

Yet again, to others the spiritual and temporal aspects of the term cannot be separated, but intertwine. According to Loch: "In the word 'charity' religious and social associations meet; and thus regarded the word means a disciplined and habitual mood in which the mind is considerate of the welfare of others individually and generally, and devises what is for their real good, and in which the intelligence and the will strive to fulfil the

24 On reconciliation, see Hodder-Williams, Judges and Politics in the Contemporary Age (1996), 36; and Crick, In Defence of Politics n 21 above, 21.

25 The last two speakers at the Annual Arnold Goodman charity lectures, the President of the World Bank, Jim Wolfensohn, and the Cardinal Archbishop of Westminster, Basil Hume, developed this theme of good government: see $14^{\text {th }}$ Arnold Goodman Lecture (1997) and 'Searching for Purpose: God and The Future of our Society', 15 th Arnold Goodman Lecture (1998). On the presence of common values in a democratic political system see further the comments of the Catholic Bishops' Conference of England \& Wales in The Common Good (1996), para 34.

26 For an examination into the origin of the word 'charity' see Gladstone n 12 above, 9 and chapter 1 generally.

27 Story, Commentaries on Equity Jurisprudence as administered in England and America (14th ed by W. H. Lyon, 1918), Vol. III, 175, n 3.

28 For example, the first letter of St Paul to the Corinthians chapter 13, verse 2 (if I have not love I have nothing); Leviticus 19:18, St. Matthew 22:39 and St. James 2:4-8 (call to love your neighbour as yourself); St. Luke 10:25-37 (parable of the Good Samaritan); St. Matthew 25: 34-40 (provision of food and clothing for the hungry and naked stranger). 
mind's purpose." 29 Indeed, in discussing charity, St Thomas Aquinas put forward not only seven spiritual deeds (to counsel, reprove, console, pardon, forbear, instruct or to pray) but also seven corporal deeds (to visit, quench, feed, ransom, clothe, harbour or bury) as instances of charitable acts.

Demonstrated within these definitions is the association of charity with the taking of an action and the achievement of a purpose. So too is this emphasis upon deed and objective carried through into charity law. The legal framework validates ad hoc acts which lead to the attainment of a specific and defined purpose, eschewing uncertain or ill-defined notions of benevolence. ${ }^{30}$ One need only examine the contents of the Preamble to the Act of Charitable Uses 1601, which framed the development of the modern law of charity, with its emphasis upon amelioration and restoration to find a purposive approach carried through into charity law. ${ }^{31}$ Further, in the context of charitable trusts for the advancement of religion, this purposive approach can be particularly noted through the emphasis of the law upon palpable deeds rather than ethereal acts of faith. ${ }^{32}$

However, the aims of charity, though now artificially demarcated into the relief of poverty, advancement of education, advancement of religion and other purposes beneficial to the community by Lord Macnaghten in Commissioners for Special Purposes of Income Tax v Pemsel, ${ }^{33}$ are more rudimentary. On one dimension, the purpose of charity may be said to be benevolence, that is the simple act of redressing need. This first dimension identifies charity with the poor. Poverty in this sense is construed widely and beyond financial restrictions to mean those within society who have a fundamental lack of opportunities and choices for action. $^{34}$ This powerlessness may exist, for example, in a person's or a community's material, cultural, educational, physical, mental or spiritual needs. The poor are thus "those without sufficient means to take part in the

29 Loch, Charity and Social Life: A Short Study Of Religious \& Social Thought In Relation to Charitable Methods \& Institutions (1910), 1.

30 See Chichester Diocesan Fund \& Board of Finance (Inc.) v Simpson [1944] AC 341.

31 The Preamble provided a wide, although not comprehensive list of charitable purposes: "The relief of aged, impotent and poor people; the maintenance of sick and maimed soldiers and mariners, schools of learning, free schools and scholars in universities; the repair of bridges, ports, havens, causeways, churches, seabanks and highways; the education and preferment of orphans; the relief, stock or maintenance of houses of correction; the marriage of poor maids; the supportation, aid and help of young tradesmen, handicraftsmen and persons decayed; the relief or redemption of prisoners or captives; and the aid or ease of any poor inhabitants concerning payment of fifteens, setting out of soldiers and other taxes."

32 Gilmour v Coats [1949] AC 426, cf Neville Estates Ltd v Madden [1962] Ch 832 and Society of the Precious Blood (1995) 3 Decisions of the Charity Commissioners 11 .

33 [1891] AC 531, 583.

34 Actionaid, Bridging the Poverty Gap (1993), 3. In Re Coulthurst [1951] Ch $661,665-6$, 'poverty', under the specific heading 'relief of poverty' in charity law, was defined as encompassing those people 'going short'. This definition appears to be restricted to financial matters. The EC working definition of poverty states that: "the poor shall be taken to mean persons, families and groups whose resources (material, cultural and social) are so limited as to exclude them from the minimum acceptable way of life in the member states in which they live", Bull. EC 12-1984, pt2.1.95. 
life of the community ... excluded from the community, and ... denied the rights of membership. ${ }_{35}$ In specifically directing attention to redressing need within society, acts of charity and the legal framework within which they operate exhibit a focus upon poverty. In providing opportunities and choices, this focus may be termed the providing of an option for the poor'.

But on a second dimension, the putting into effect of that benevolence and the act of redressing need reveals charity's more fundamental aims and nature. In its association between relieving and doing, or in Loch's words "striving to fulfil the mind's purpose", ${ }^{36}$ charity necessitates a look beyond the immediate need to tackle the cause. At this level charity more specifically represents a 'call to action', and is typified by innovation, effecting change, searching for solutions, pushing the boundaries, challenging existing order, being a "creative ferment in a free society", 37 giving a reason for hope and providing the opportunities and choices that the poor lack. The call to action which this second dimension involves is itself complex. It does not associate charity with the challenging of world order, but it does provide for a critical appraisal of society and of the elements within a community which cause or sustain a broad view of poverty. ${ }^{38}$ The truly charitable act thus goes beyond the mere redressing of need to the point where it is concerned by purpose or deed with transforming society. It is only when both dimensions are transcended that charity is fully formed.

\section{IDENTIFYING COMMON GROUND}

A distinction is often made in this debate between the end, or purpose, of a charity and the means by which that end is achieved, as a way of differentiating charitable acts from political acts and justifying the legal restrictions placed upon charities. ${ }^{39}$ The argument is that the charitable end or purpose determines what is the common good, ${ }^{40}$ and that political

35 John Paul II, Encyclical letter: Sollicitudo Rei Socialis (On Social Concerns), 30 December 1987, para 74.

36 n 30 above, 1.

37 Per Lord Dahrendorf, HL Deb vol 586, col 1271-1272 4 March 1998 and HL Deb vol 576 col, 31527 November 1996.

38 Charity's intrinsic connection with the political does not mean that an organisation has to undertake political or campaigning activities in order to be charitable. Rather, that within a charitable act lies the potential for a moral outpouring, whereby the understanding which charity gives of another's poverty can lead to a desire to redress not just the manifestations of that poverty, but also its causes. The moral purpose of charity is a call to action, but that call to action is enabling and not prescriptive. That is why charity may be described as a political option for the poor.

39 The Ontario Law Reform Commission, for example, argue that since charity is the good, and politics only a debate about the good, the two must be distinguished, albeit that they do agree that "politics is the process of a society's collaborative effort to make law, to come to some agreement or understanding on a particular determination of the good": Report on the Law Of Charities, (1996) chapter 6.

40 The Ontario Law Reform Commission have argued that "the truly charitable act is the act whose form, actual effect and move are the provision of the means of pursuing a common or universal good to persons who are remote in affections and to whom no moral or legal obligation is owed." ibid chapter 6 . The Commission draw upon the work of Finnis in Natural Law and Natural Rights 
activities are no more than one means by which the common good can be achieved. Because the distinction between ends and means argues that the charitable and the political are, in principle, different and concerned with separate issues - the former determining the common good, and the latter a tool to achieve that good - it follows upon this view that the charitable foundation of the common good does not intrinsically involve a political element. Crucially, this denies a role for the political purpose or substantial political act because, under the current law, a charity's purpose and the means used to achieve that purpose must be wholly and exclusively charitable. A purpose will be charitable and thereby concerned with the common good if it falls within Lord Macnaghten's four heads of charity, identified earlier. ${ }^{41}$ A substantial political act or purpose cannot be an end in itself because it does not fall within one of Lord Macnaghten's categories and is not wholly and exclusively charitable. A political activity will be acceptable as a means to achieve a charitable end, but only if it falls within the ambit of an ancillary act. If the political act is and remains ancillary to the charitable purpose, as Slade $\mathrm{J}$ pointed out in McGovern v Attorney General, ${ }^{42}$ it will be deemed a charitable act in itself, but if it is not ancillary to the charitable purpose it will remain political in nature and thereby be unacceptable.

Though ostensibly plausible, these distinctions present a delineation of the two spheres of charity and politics in the starkest of terms and pay no credence to the fundamental nature of politics and charity. As noted in the preceding sections, the charitable and the political are unified at a fundamental level by their association with the promotion of a common good - a public benefit - and thus providing the poor with choices and opportunities. ${ }^{43}$ What is deemed a 'good' and charitable to achieve in one community will in fact be determined in the community's prevailing social context. The prevailing social context is, in turn, partly or wholly determined by cultural and political considerations or assumptions either on a micro or macro-level. Whether these political considerations reflect no more than the historical location and development of a particular community, or whether they more properly represent the prevailing philosophy of a governing régime, they are nevertheless inherently used to define the good which it is deemed by society as charitable to pursue.

Whilst there is much to commend their congruency, this is not to argue that every political purpose or activity will be consistent with a charitable purpose or activity. Clearly, the charitable and the political are not wholly synonymous. There are many different political ideologies, and not all ideologies will be compatible with charity or share the same construct of the common good. Even some dimensions of accepted ideologies may raise concern as being for the public benefit. In this respect the challenge for the legal framework is to work with an interpretation of the common good, or public benefit, which capitalises upon the ground between the

(1980), chapter 4, to identify common or universal goods and to show how charity can provide for such goods.

41 See text to $n 34$ above.

$42 \mathrm{n} 9$ above, 341. See also the discussion of the same issue by the Court of Appeal in $R \vee$ Radio Authority, ex $p$ Bull $\mathrm{n} 17$ above.

43 The Government in introducing its 'Compact' with the voluntary sector identified the common ground between the political arena and the wider voluntary sector on the basis of their shared 'aspirations', these being, "the pursuit of inclusiveness, dedication to public life, and support for the development of healthy communities": Compact on Relations between Government and the Voluntary and Community Sector in England Cm 4100 (1998), foreword. 
two spheres, but which does not debase the notion of charity to an unacceptable political realm. Propaganda or partisan political activities must surely fail a test of common good where they are neither, in Story's view of charity, "free from the stain or taint of every consideration that is personal, private or selfish", 44 nor, as Loch stated, widely "considerate of the welfare of others". ${ }^{5}$ The problem of where the line should be drawn between palatable and unpalatable politics is presently obviated by the law's restriction on charities undertaking substantial political activities and the blanket restriction on political purposes. It is true that the political and non-political boundary will not necessarily become less problematic if rendered less arbitrary. But just as Clark noted that the "need for information and ideas is not diminished because the issue is controversial", ${ }^{46}$ so too the expediency for the law to finely balance legitimate interests is not diminished simply because it is difficult to draw boundaries, particularly if the boundary presently so drawn represents an artificial severing of political considerations from charity's core.

\section{THE THEOLOGY DEBATE}

The dimensions of charity identified above can be explored more fully by making a comparison of the charity and politics debate with a similar debate in the theological arena. The sphere of theology and politics is particularly relevant in this context, not simply because of the Christian association of charity with love, but also because at a fundamental level it resonates with the problems encountered in the charitable sphere. Moreover, in terms of development, theology is more advanced, and the process of analysis and rationalisation it has undertaken may illuminate the debate in the context of charity, and help formulate a more feasible framework for the development of charity law.

\section{Liberation Theology As A Comparable Model For Charity}

The dynamic relationship of politics with hermeneutics developed through a particular Catholic movement termed 'liberation theology', 47 In short, liberation theology emphasises social, economic, political, racial, environmental, military and spiritual liberation. ${ }^{48}$ Liberation theology's meaning and purpose can be found in the fact that "it is the articulated cry of the oppressed", "puts on agenda for discussion questions that concern all human beings", "denounces the causes that produce oppression and inspires an outpouring of generosity destined to overcome destructive

44 n 28 above, Vol III, 175, n 3.

45 n 30 above, 1.

46 n 4 above, 458. For a similar argument see Waldron, "Religious Contributions in Public Deliberation" (1993) 30 San Diego Law Review 817, 841-842.

47 For a good introduction see Kirk, Liberation Theology: An Evangelical View from the Third World (1979).

48 Norwood Evans, "Liberation theology, empowerment theory and social work practice with the oppressed" (1992) 35 International Social Work 135, 139. The theological themes are discussed by Boff \& Boff, Introducing Liberation Theology (1987), 49-63. See also Gutiérrez who argues that liberation theology is essentially "a theological reflection born of the experience of shared efforts to abolish the current unjust situation and to build a different society, freer and more human" which gives a "reason for our hope from within a commitment that seeks to become more radical, total, and efficacious," A Theology of Liberation: History, Politics and Salvation (1971), xiii. 
relationships and build freedom for everyone", and "sets out to be the servant of faith that works through charity inspired by hope". ${ }^{49}$

Liberation theology's primary tenets were developed, among others, by the Peruvian theologian Gustavo Gutiérrez in the late $1960 \mathrm{~s} .{ }^{50}$ It was formally determined by the Latin American Bishops at Medellín, Columbia in 1968 and ratified eleven years later at the conference in Puebla. In a statement issued by the Bishops at Medellín, the essence of liberation theology and its association with the poor was laid down as an obligation: "to sharpen the awareness of our duty of solidarity with the poor to which charity leads us. This solidarity means that we make ours their problems and their struggles, that we know how to speak with them.' Moreover, it means that our charitable relationship with the poor:

"has to be concretised in criticism of injustice and oppression, in the struggle against the intolerable situation which a poor person often has to tolerate, in the willingness to dialogue with the groups responsible for the situation in order to make them understand their obligations." 51

Within the concept of liberation theology there are two themes, both of which are directly comparable with the dimensions of charity already identified. In the first instance liberation theology teaches that charity leads to solidarity with the 'poor'. John Paul II stated in his encyclical letter Sollicitudo Rei Socialis (On Social Concerns) (22 $^{52}$ that solidarity:

"is not a feeling of vague compassion or shallow distress at the misfortunes of so many people, both near and far. On the contrary it is a firm and persevering determination to commit oneself to the common good; that is to say, to the good of all and of each individual."

In the context of solidarity charity means "being-for-others", 53 identifying with their poverty and seeking redress of that poverty. This was expressed earlier as the first dimension of charity - providing an 'option for the poor'. But in the context of liberation theology, charity in a one dimensional sense is inadequate. A further step is required. As has been argued, "... in the social dimension, loving means collaborating in the formation of new structures, supporting those that represent an advance in the campaign for a better quality of life, and political commitment in favour of an option for solidarity with the poor." 54 Thus it is only when charity goes to the essential quality of solidarity that it becomes complete. Within liberation theology, solidarity demands the criticism of injustice and oppression and dialogue to effect change. In fact, solidarity or charity - "being-for-others" - means nothing unless it is coupled with attempts to mediate or change an unjust or intolerable situation. This leads to the second theme of liberation theology, termed "subsidiarity": 55 the call to action.

49 Boff \& Boff Introducing Liberation Theology (1987), 88-89.

50 His main thesis is contained in A Theology of Liberation: History, Politics and Salvation (1971).

51 Bishops of Latin America, Medellín document Poverty of the Church, 6 September 1968, paras 9-10.

52 n 36 above, para 38.4 .

53 Phrase taken from Boff \& Boff, n 50 above, 62.

54 Boff \& Boff, n 50 above, 62.

55 For a discussion of subsidiarity see Duff (ed.), Subsidiarity within the European Community (1993); Ward n 23 above. 
Gutiérrez described liberation theology as "a political hermeneutics of the Gospel", ${ }^{56}$ and the theme of subsidiarity as a tenet of liberation theology is concerned with the questioning of the situation of the poor in order to challenge and change the circumstances which lead to poverty. The notion of 'subsidiarity' is becoming increasingly common. It is one of the concepts that lies at the heart of post-Maastricht European law, ${ }^{57}$ though its ambit is neither fully drawn out, nor sufficiently hemmed in. As Peterson $^{58}$ has argued, it stands as a concept which is amenable to support competing ideologies rather than accommodating different views. In whatever sense subsidiarity is eventually interpreted, on a basic level it involves the premise that power and contribution to decision-making should be delegated downwards from the political and governmental institutions to the people. Indeed, it can be seen as supporting "a dispersal of authority as close to the grass roots as good government allows ... [preferring] local over central decision making." 5

Subsidiarity is more than just a theory, indeed its existence and gradual dissemination explains Beck's identification of a change in the construct of the political arena of post-industrial society and consequently the increase in micro-level political activity. ${ }^{60}$ Moreover, as a tenet of liberation theology it leads to a further correlation with the charitable and political arenas. That connection relates directly to their wider schematic purpose for action. At the heart of the Latin American Bishops' Medellín statement is the broad purpose of bringing the poor out of their poverty into participation for the benefit not just of the individual poor, but of the community as a whole. ${ }^{61}$ Not only does liberation theology exhibit the two themes of an option for the poor and a call to action but, like charity and like politics overall, in transforming society it has as its aim the achievement of public benefit through the pursuit of a common good, a shared social purpose, a shared social value.

56 n 51 above, 13.

57 See Art. 5 European Community Treaty.

58 He identifies three competing constructs of subsidiarity: the wide view based on Catholic social teaching which dictates that "small social groups should be autonomous and sovereign in a pluralist society, yet united in a common morality which stress duty and harmony ... assisted in their activities by the state which neither substitutes for social groups nor is it shackled by their demands, but which serves the public good and provides legal order". Secondly, the more rigid federalist view of Germanic origin which defines the respective powers, duties and roles of different levels of government. Thirdly, the 'British conservative ideology' which sees subsidiarity as a means by which supranational powers can be limited. He argues for a broad definition: Peterson, "Subsidiarity: A Definition to Suit Any Vision?" (1994) 47 Parliamentary Affairs 116, 118-9 and 128-130. See also Teasdale, "Subsidiarity in PostMaastricht Europe" (1993) 64 Political Quarterly 187.

59 Catholic Bishops' Conference of England \& Wales, The Common Good n 26 above, para 52.

60 See text to $n 19-23$ above.

61 See, for example, the Medellín document Justice, 6 September 1968, para 16. 


\section{Criticisms Of Liberation Theology And Their Parallel In Charity Law}

The connection of theology with politics served to cause much debate and criticism both within and without the Vatican. ${ }^{62}$ The core criticisms centred upon the problems of distortion, legitimacy and exclusion.

To take the first criticism, that of distortion, there existed the fear of the impact which liberation theology's twin notions of solidarity and subsidiarity could have directly upon either the church and its members or upon the political process. This manifested itself particularly in an institutional anxiety over the development of a predominantly Marxist theme, and the fear that actions taken by liberation theology's actors for the poor and to relieve poverty would become simply a secular philosophy. ${ }^{63}$ Secondly, the Church recoiled from embracing liberation theology on the basis that controversial political acts undertaken by church representatives in pursuit of, say, opposing oppressive régimes, could be popularly perceived to be legitimised by the Church from the fact that the actors' actions fell within the auspices of a recognised institution. This criticism further introduces its corollary that sustained controversial politicking would bring opprobrium or disgrace upon the Church as the institution represented by the liberation theology actors. Thirdly, liberation theology was criticised as being exclusionary. First per se, because it concerned a Christian notion, and secondly because it could lead to the dogmatic insistence upon the application of Christian or politico-Christian doctrine in all or in inappropriate circumstances. ${ }^{64}$

Significantly, the criticisms raised did not seek to deny the political nature of charity as expressed in a theological framework. Rather, they demonstrated a wariness over the extent of the consequences of the association. These criticisms and their concern with external consequences rather than challenging inherent characteristics, find their parallel in the arguments which traditionally censure the association of charity with politics in law.

In the context of the criticism of distortion, for example, the boundaries within the legal framework reflect a general apprehension over the consequences of a clear political role for charities. Aside from the perceived distortion of charity's good name and the alienation of donors ${ }^{65}$, an option for the poor and a call to action by charities may lead, it is thought, to a distortion of the political process through the promotion of

62 In particular by Cardinal Ratzinger on behalf of the Congregation for the Doctrine of the Faith. These objections are considered in greater detail in Berryman, Liberation Theology: Essential Facts about the Revolutionary Movement in Latin America and Beyond (1987), chapter 12.

63 That is, redemption through temporal actions rather than through recourse to God.

${ }^{64}$ In fact this has proved not to be the case in comparisons of liberation theology working in different social and cultural environments. See, for example, the observations of Wilfred in the context of the inter-faith Indian experience of liberation theology: "Action Groups and the Struggle for Justice in India: Ecclesiological Implications” (1987) 39 Ecumenical Review 291.

65 This was one of the contentions employed by the Government in their White Paper, see n 5 above, to argue against allowing charities to campaign or act politically in any manner other than that which was ancillary to and in furtherance of their main charitable purpose. 
biased or unbalanced information and policies, the use of undue or emotive public pressure rather than reasoned argument, or through an overt emphasis upon a single issue which may have the effect of diverting political debate from the main issues of the day. Anxiety over this form of distortion of the political process either by charities directly, or indirectly by taxpayers' subsidy of charitable activity, has been highlighted by the Charity Commission and the Government. ${ }^{66}$ With regard to the latter's view, it represents a wider concern with independence and autonomy, particularly in the electoral process. ${ }^{67}$ This concern has some foundation given the wide support and trust reposed in charities and the subsequent political muscle that they and their supporters could flex.

With regard to legitimacy, in charity law there is concern that since charities are legitimised through their charitable status generally and their taxation concessions specifically, any political actions undertaken will be automatically endorsed, or perceived to be endorsed, precisely because they take place within the auspices of a recognised legal framework. Similarly, there is concern that sustained controversial political acts will only serve to bring opprobrium or disgrace upon that framework, and de facto upon the actors within it, including any non-politically acting charities.

Finally, predominant political action by charities may lead to exclusion through partisan political influence or bias, or through the imposition of fundamental political dogma under the guise of charitable works. The law is vigilant to prevent political propaganda masquerading as charitable purposes and particular attention is paid to those purposes which seek to fall within the head of advancement of education, an area most susceptible to manipulation. ${ }^{68}$ This concern with the consequences of accepting

66 The Government's view in its White Paper was that the taxation subsidy given to charities meant that taxpayers were subsidising political activities, and that it "would be wrong if taxpayers ... were to find themselves unwittingly distorting the democratic process by subsidising bodies whose true purpose was to campaign not so much for their beneficiaries as for some political end," $\mathrm{n} 5$ above, para 2.41. The Charity Commission's emphasis upon not distorting the political process and upon presenting well founded and reasoned material can be found throughout their guidelines on the political and campaigning activities of charities, $n 6$ above.

67 The problem of the distorting effect upon the democratic process of the pursuit of single issues by interested groups was emphasised by the Government in their submission to the European Court of Human Rights in Bowman $\mathrm{v}$ UK (1998) 26 EHRR 1, in which Bowman successfully challenged section 75 of the Representation of the People Act 1983 on the basis that it concerned a breach of freedom of expression under Article 10 of the European Convention on Human Rights. In his dissenting opinion, Judge Sir John Freedland re-emphasised the distortion point. He stated at para 13: "the role played by single issue pressure groups in influencing and mobilising public opinion in modern democracies is, as the Government acknowledged, an important one. But a factor of which the State may legitimately take account in determining the regulation of the electoral process is the extent to which limits of the funding of single-issue campaigns at parliamentary election may be needed in order to counter the risk of excessive diversion of the main electoral debate."

68 See Vaisey J in Re Hopkinson [1949] 1 All ER 346, 350; McGovern v Att Gen n 9 above; Southwood v Att Gen The Times, 26 October 1998; and the Charity Commission Guidelines n 6 above, paras 45, 52, 54; cf Re The Trustees of the Arthur McDougall Fund [1956] 3 All ER 867; Re Koeppler's W.T. [1986] Ch 423; Re Scowcroft [1898] 2 Ch 638. 


\section{Northern Ireland Legal Quarterly [Vol. 50, No. 3]}

partisan political purposes within the definition of charity is the kernel of the law's objection against greater latitude for charities to campaign or otherwise act politically. It lies at the heart of the Government's refusal to reconsider reform of the definition of charity, since in their view the present law provides an 'indispensable safeguard' to donors, taxpayers and the public generally. ${ }^{69}$

The criticisms of distortion, legitimacy and exclusion do not go to the base or the essence of either liberation theology or charity and do not represent a challenge to their prevailing principles. Rather, they focus upon external considerations which are the perceived and preconceived consequences of undue political action. Solidarity, an option for the poor, and subsidiarity, a call to action, mean pushing the boundaries of a system, but nevertheless working within that system to change, strengthen or alter its direction. ${ }^{70}$ Distortion, legitimacy and exclusion are objections which would be raised in any system which sought but had not completely implemented a strong civil society. In such a system there is an onus upon government to govern responsibly. ${ }^{71}$ This does not simply mean fairly and justiciably, it also means having the strength not only to encourage pluralism and diversity, but also to avoid distortion and exclusion in the face of strong pressure, to foster consultation and collaboration and to provide a framework which respects true legitimacy.

\section{THE WAY FORWARD}

Despite the criticisms of liberation theology for pushing the boundaries of the system, its value lies in the fact that it forced an institutional reconsideration of the position to which faith leads. The Church's response to the challenge of liberation theology stands as a prime example of the benefit which can be brought from analysing the foundation of an area. It has allowed the political nature of charity to be harnessed with theological teaching in a manner which is acceptable in the current global and ecclesiastical climate.

Although initial attempts were made to deny the political manifestations of faith in action, in fact by challenging liberation theology the Church was led to focus its attention on the foundation of faith and the call of the Gospels. This reappraisal in turn led to a renewed institutional emphasis upon the Church's social teaching through which it highlighted the need for an active "preferential option for the poor". ${ }^{72}$ This institutionally organised focus upon poverty takes as its root the community's individual and collective obligation to pull the poor out of their condition by means of spiritual and temporal acts. It places an emphasis upon working within a system to bring about change. In the context of the present discussion, the significant feature of the Church's renewed emphasis upon social teaching and its preferential option for the poor is that it not only more fully reflects the Gospels' call to action, but that it also differs little from

${ }^{69}$ Charities: A Framework for the Future n 5 above, para 2.41.

70 So too in the context of liberation theology, a theology which Gutiérrez termed 'the activity of "peacemakers", in A Theology of Liberation: History, Politics and Salvation $\mathrm{n} 51$ above, $\mathrm{xxx}$.

71 According to Tony Blair's vision for the development of the 'third way' in politics, "a key challenge of progressive politics is to use the State as an enabling force, protecting effective communities and voluntary organisations and encouraging their growth to tackle new needs, in partnership as appropriate", The Third Way: New Politics for the New Century (1998), 4.

72 See most recently John Paul II's Apostolic Letter: Tertio Mellenio Adveniente (As the Third Millennium Draws Near), 14 November 1994, paras 50-51. 
the original vision of liberation theology which was first rejected as politically unacceptable. The crucial distinction is that the moves to put faith in action with regard to the poor are now sanctioned and regulated by the Church. ${ }^{73}$

The framework of charity law needs to undertake a similar rationalisation in order to more fully reflect the arena which it regulates. Without an examination of the foundations of charity the restrictions currently in place will be found wanting where they fail to accommodate the inherent nature of charity. As highlighted earlier, at a fundamental level the charitable and the political arenas are unified by their association with the promotion of a common good, a public benefit. Recognising this connection would do much to obviate the difficulty presented by the principal arguments advanced for prohibiting charities from undertaking substantial political activities or purposes: that is, that the judiciary cannot be the arbiter of whether a political activity satisfies the requirement in charity law for a purpose to be for the public benefit; ${ }^{74}$ and that, in any event, the judiciary must remain politically neutral and not become embroiled in debates over the legitimacy of diverse political purposes. ${ }^{75}$ These arguments pertain to points concerning justiciability and seek to place charity law beyond the reach of partiality by distancing the decision-making process from controversial issues which would reflect upon the legal framework and the legitimacy of the separation of powers.

Justiciability is an important issue and one should not seek to place within legal consideration issues which are beyond the scope of the judiciary. However, aside from side-stepping the fundamental nature of charity, these arguments in fact obscure the environment within which decisions in charity law are taken. First, in the context of political activities used to achieve a charitable purpose, the charitable purpose itself will have already passed the test of public benefit when the organisation in question applied for charitable status, since it is at the point of registration that the organisation's express objects clause is subject to scrutiny. Public benefit is considered in the context of assessing if the purpose in the objects clause is charitable, not in the context of how that purpose is achieved.

Secondly, with regard to political purposes and public benefit, public benefit as construed in charity law is a tangible benefit afforded to a crosssection of society which is not numerically negligible. ${ }^{76}$ So construed, such a test has the capacity to be applied irrespective of the colour or nature of the purpose. Concern may, of course, be expressed as to the

73 See, for example, Paul VI's Apostolic Exhortation: Evangelii Nuntiandii (On Evangelisation in the Modern World), 8 December 1975, paras 25-39. Catholic social teaching has long lauded the use of 'intermediate groups' within a democracy to effect change and to help man reach his full potential, seeing such groups as "the indispensable means to safeguard the dignity of human person and freedom while leaving intact a sense of responsibility" (John XXIII's Encyclical letter: Pacem Terris (Peace on Earth), April 1963, para 24 and see also para 35 ). So too, has there been a strong emphasis upon civil society and upon each person becoming "the artisans of their own destiny" (Paul VI's Encyclical letter: Populorum Progressio (On the Development of Peoples), 26 March 1967, para 65).

74 An argument once described as "a strain on credulity": Sheridan, n 4 above, 58.

75 Bowman v Secular Society Ltd, n 9 above; National Anti-Vivisection Society v IRC, n 9 above.

76 See Lord Westbury in Verge v Somerville [1924] AC 496, 499; Lord Simonds in Oppenheim v Tobacco Securities Trust Co. [1951] AC 297, 306; Gilmour v Coats n 33 above, 446; Dingle v Turner [1972] AC 601. 


\section{Northern Ireland Legal Quarterly [Vol. 50, No. 3]}

dilemma caused to the judiciary in assessing the benefit afforded to a cross-section of society by politically opposed right-wing or left-wing purposes. But the key to the public benefit test is not the approach or ideology taken to the purpose, but whether the purpose per se provides a benefit. By way of comparison, if, as is the case, the tenor of spiritual belief is irrelevant to the public benefit test for charitable purposes falling within the head of religion, ${ }^{77}$ so likewise should it be for the tenor of political belief. Further, in the context of charitable status, the restriction against unacceptable political activities currently de facto implied into each charitable purpose means that the judiciary are already in the process of accepting that a charity's express object clause is limited, and limited so to exclude what the law presently deems to be inappropriate activities. This decision is in itself politically charged. ${ }^{78}$

Moving forward from a consideration of charity's inherent nature, how the association between the charitable and the political is to be harnessed is open for debate, but represents the challenge to contemporary charity law. Sheridan's view is that the law should take into account political considerations by returning specifically to the spirit and intendment of the Preamble to the 1601 Act of Charitable Uses. ${ }^{79}$ The spirit of that Act however, was bound up with Elizabethan reform and seventeenth century social concerns. What is more pertinently required is a move forward which would enable charity law to transparently reflect the essence of charity within the context of the current social and political climate. The American position ${ }^{80}$ of permitting charities to be politically active but with a prescription upon the funds and general resources that can be so dedicated is a quantitatively artificial solution which would not meet this challenge of transparency. Neither would the setting up of a separate body to make decisions upon charitable status, ${ }^{81}$ since the problems of partisan politics, or construing the public benefit would be simply transferred between bodies. The view that the market should be allowed to decide whether or not to support charities who actively enter into the political arena is attractive, ${ }^{82}$ but holds some reservations for protecting against the dissemination of propaganda or unpalatable political acts under charity's badge of credibility.

Charity's nemesis is the taxation advantages with which it is afforded. Any re-examination of charity law must take into account charity's privileged financial status, given that it is fiscal policy which lies at the heart of current charity regulation. One option could be to sever the fiscal

77 As Cross J stated in Neville Estates Ltd v Madden [1962] Ch 832, 853, “As between different religions the law stands neutral". Consider also Thornton v Howe (1862) 31 Beav 14; Varsani v Jesani [1998] 3 All ER 273; cf Re South Place Ethical Society [1980] 1 WLR 1565.

${ }^{78}$ See Rickett, n 4 above, 170. It remains true that in certain areas the judiciary have not shied away from the political ramifications of their decision-making. Consider in this respect the judiciary's revolutionary approach to tax avoidance schemes in W. T. Ramsay v IRC [1982] AC 300, which came as a significant departure from the more lenient approach previously adopted in IRC $\mathrm{v}$ Duke of Westminster [1936] AC 1. On the significance of the judicial change see Lord Diplock in IRC v Burmah Oil [1982] STC 30, 32.

79 n 4 above.

${ }^{80}$ See Hopkins, Charity, Advocacy \& The Law (1992).

${ }^{81}$ A view put forward by Hackney, "The Politics of Chancery" (1981) 34 CLP $113,127-8$.

82 See, for example, the arguments of Sprince, "Political Activity by Charitable Organisations: An English Model with More to Learn than to Teach?" (1997) 11 TruLI 35. 
line wholly, another to place an additional tax upon political activities so defined. ${ }^{83}$ A third view could be to grade taxation privileges according to the nature and extent of the political activities undertaken. ${ }^{84}$ The question of the taxation advantages of charities is a particularly thorny issue, and one which demands detailed attention in all respects of charitable activity, from main charitable purposes to subsidiary activities, such as charity trading, though a key issue, altering the fiscal privileges in respect of political activities, would not be feasible in practice without a commitment to wholesale reconsideration of the taxation structure..$^{85}$

Perhaps the most preferable way forward would be to permit certain categories of charities more latitude in respect of political considerations. There are a number of ways in which this could be implemented, albeit that some means would be more feasible than others. It could be achieved outright by permitting only those charities which fall within a particular category to undertake substantial political activities or purposes, or, less artificially, it could be achieved through permitting greater political latitude for those charities whose purposes specifically aim to provide opportunities and choices for the poor. This latter method, however, may lead to problems of arbitrariness and would question the criteria involved in decision-making.

A third approach to this proposal could be to isolate those charities involved in partnership with, and in receipt of funding from, central or local government, since it is arguable that only those charities truly independent of government that should have the freedom to engage in political activities. One advantage of this proposal is that it would exclude charities which may have political backing from unfairly influencing their members, the wider public or distorting the political process. However, it would present an unwarranted dilemma for the many charities which wish to partake in the political arena but who, in the present highly competitive market economy, rely upon government contracts for their continued existence. $^{86}$ Further, this approach would seem to be at odds with the Government's more recent moves to create a 'compact' with the wider voluntary sector. ${ }^{87}$ The role of the voluntary sector within the political arena has long been lauded as an essential prerequisite for a healthy civil and political society, ${ }^{88}$ and the Government's compact has emphasised the unique contribution to a socially inclusive democratic society which is

83 See 6 \& Randon $\mathrm{n} 4$ above.

${ }^{84}$ HRH Prince Phillip put forward a similar view for an overall redefinition of charity in giving the 1994 Annual Arnold Goodman charity lecture: 11th Arnold Goodman Lecture (1994).

85 Consideration of the taxation structure is currently being undertaken by the Treasury: see Review of Charity Taxation Consultation Document: HM Treasury, March 1999.

86 See further Knight, Voluntary Action (1993).

87 Compact on Relations between Government and the Voluntary and Community Sector in England Cm 4100 (1998). See also Blair, The Third Way: New Politics for the New Century (1998).

88 For example, the Wolfendon Report in the late 1970s, in calling for decentralisation of power and greater involvement for the individual in decision-making, expressed the view that there was room for a number of methods to relieve need within society, such as an informal system of social help through a network of friends and family, a commercial system of private education, health care and pensions, the statutory system of welfare provision and the voluntary system: The Future of Voluntary Organisations: Report of the Wolfendon Committee (1978), 22. 


\section{Northern Ireland Legal Quarterly [Vol. 50, No. 3]}

made by voluntary groups through their role in working with and on behalf of the vulnerable or disadvantaged ${ }^{89}$ It would not be consonant with this approach to artificially exclude those charities in partnership with government from a political role when other voluntary groups in similar partnerships are not so limited. Further, as noted earlier, ${ }^{90}$ distortion of the political process by charities campaigning whilst acting in partnership with government should not be sustainable in a strong civil society.

A fourth alternative is that the proposal for allowing only a certain category of charities to act politically could be more sensitively achieved through reconstructing the test for public benefit as it applies across Lord Macnaghten's four heads of charity. Lord Cross in Dingle v Turner ${ }^{11}$ long favoured a qualitative approach to charity law which assessed purposes by fact and degree. A similar approach which qualitatively assessed tangible benefit to a sufficient cross-section of the public, with a concentration upon the substance of the purpose rather than its form or method, could be utilised here. Political purposes which offered tangible benefit to the common good would not be debarred because of their apparent colour, but would not be admitted without evidence of their essentially charitable nature. This latter method would be advantageous in the context of ensuring that those political activities which militate against a socially constructed common good, such as partisan policies or terrorist acts, remain outside and are not embraced within charity's ambit.

\section{CONCLUSION}

Allowing charities more latitude in the political arena will not obviate the many substantial difficulties involved in creating a workable framework for regulation. Indeed, rendering the distinction between the political and non-political sphere less arbitrary will, if anything, place greater emphasis upon the requirement for a strictly accountable system. What is at stake is the question of policy. In the end the choice is whether protection of the democratic process is placed higher than the ability of all interested groups to contribute to that process. If on public policy grounds the status quo of the current law is to be ultimately enforced, it is vital that a whole or partial restriction against political involvement should be in place only in the face of a full and frank analysis of charity's foundation, rather than simply upon fears of where an overt political connection may lead. A selfcritical reconsideration of the foundations of charity and of charity law is necessary if its legal framework is to be both respectable and successful.

89 n 88 above, paras 5-7.

90 See text to $n$ 71-72 above.

91 n 77 above. See also Lord Porter's dissenting judgment in National AntiVivisection Society v IRC n 9 above. 